\title{
Red fruit oil increases trophoblast cells and decreases caspase-9 expression in placenta of lead exposed mice
}

\author{
Portia Sumarsono*, Widjiati**, and Suherni Susilowati***
}

\begin{abstract}
*Department of Veterinary Anatomy Veterinary Faculty, Airlangga University

**Department of Veterinary Anatomy, Veterinary Faculty,

Airlangga University

***Department of Veterinary

Reproduction, Veterinary Faculty,

Airlangga University

Correspondence :

Portia Sumarsono

Veterinary Faculty, Airlangga University

Kampus C Unair,

Jl. Mulyorejo, Surabaya 60115

Phone : +62857 46544651

Email: portia.sumarsono@gmail.com

\section{BACKGROUND}

Lead is able to pass through the placental barrier and interfere with fetal development. Red fruit has high antioxidant activity, due to carotenoids (pro-vitamin A), tocopherols (vitamin E) and unsaturated fatty acids. This study aims to examine the effect of red fruit oil towards placenta in pregnant mice before lead exposure.

\section{METHODS}

This was a laboratory experimental post test only study, using 20 pregnant mice (Mus musculus) that were randomized into five groups. The negative control group was not exposed to lead; intervention group 0 (P0) was exposed to lead at $0.011 \mathrm{mg} / 20 \mathrm{~g} \mathrm{BW} /$ day on days $6-15$ of gestation. The intervention groups P1-P3 were given red fruit orally at $0.3 \mathrm{~mL} / 20 \mathrm{~g}$ BW/day, $0.8 \mathrm{~mL} / 20 \mathrm{~g} \mathrm{BW} /$ day, $0.9 \mathrm{~mL} / 20 \mathrm{~g} \mathrm{BW} /$ day, respectively, before lead exposure. Normal trophoblast cell count and caspase-9 expression of trophoblasts were calculated. One-way ANOVA, Kruskal-Wallis and Mann Whitney tests were used to analyze the data.
\end{abstract}

Univ Med 2016;35:110-8

DOI: http://dx.doi.org/10.18051/

UnivMed.2016.v35.110-118

pISSN: 1907-3062 / eISSN: 2407-2230

This open access article is distributed under a Creative Commons Attribution-Non

Commercial-Share Alike 4.0 International License

\section{RESULTS}

The intervention groups $\mathrm{P} 2$ and $\mathrm{P} 3$ given red fruit at $0.8 \mathrm{~mL} / 20 \mathrm{~g} \mathrm{BW} /$ day and $0.9 \mathrm{~mL} / 20 \mathrm{~g} \mathrm{BW} /$ day showed a significant increase in normal trophoblast cell count of $88.2 \%(\mathrm{p}=0.024)$ and a decrease in caspase- 9 expression of $70.8 \%$ compared with $\mathrm{P} 0$ to which was not given red fruit $(\mathrm{p}=0.020)$.

\section{CONCLUSION}

Red fruit increased normal trophoblast cell count by $88.2 \%$ and decreased caspase- 9 expression by $70.8 \%$ in pregnant mice before lead exposure. It should be noted that red fuit may prevent oxidative damage to cells.

Keywords: Lead, red fruit, caspase-9, trophoblasts, pregnant mice 


\section{INTRODUCTION}

One of the heavy metals that is capable of decreasing the quality of life of humans is lead $(\mathrm{Pb})$. If lead is present in water, it will be consumed by living organisms and will ultimately cause disease and other negative impacts. Lead is capable of crossing the placental barrier of pregnant mice and accumulate in fetal tissues, so that it constitutes a potential hazard to the fetus. Lead crosses the placental membrane early in the $12^{\text {th }}$ to $14^{\text {th }}$ week of gestation, i.e. the period of organogenesis, and accumulates in the fetal tissues, with more than $90 \%$ being stored in bone and released into the circulation. ${ }^{(1)}$ Lead is an element that may increase the formation of free radicals and decrease antioxidants in the body, thus causing organ damage. The mechanism of lead toxicity is oxidative stress, which is defined as an imbalance between the amount of reactive oxygen species (ROS) produced and that eliminated by the antioxidant system. ${ }^{(2)}$

The reactive oxygen species that are formed cause hypoxia, which mediates a proapoptotic effect that is presumably involved in the mitochondrial pathway. Hypoxia may cause apoptosis of trophoblasts by decreasing Bcl-2 expression, increasing $\mathrm{p} 53$ and Bax expression, and activating caspase. ${ }^{(3)}$

One of the native Indonesian plants with a high antioxidant content is red fruit (buah merah, Pandanus conoideus Lam.). From this plant, red fruit oil may be extracted, which is highly beneficial since it has high antioxidant activity, in the form of carotenoids (provitamin A), tocopherol (vitamin E) and unsaturated fatty acids. $^{(4)}$

In the study by Dearth et al. ${ }^{(5)}$ it was demonstrated that lead concentrations in the blood of females receiving lead during pregnancy and lactation was equal to lead concentrations in the blood and tissues of their offspring, thereby also affecting hormonal levels and onset of puberty. Lead may depress insulin-like growth factor-1 (IGF-1), luteinizing hormone (LH), and estradiol (E2), thus delaying puberty. In addition, Isradji ${ }^{(6)}$ proved in his study that lead acetate affects the fertility of male mice through a reduction in the number of pregnancies and litter size of their mates. Sharma et al. ${ }^{(7)}$ reported that administration of the antioxidant vitamins $\mathrm{E}$ and $\mathrm{C}$ to mice exposed to lead was capable of improving fertility by increasing implantation rate, fetal weight and by protecting the ovaries. Red fruit can be used as a source of natural antioxidants to prevent diseases associated with free radicals. ${ }^{(8)}$

Thus there is a need to prove the protective efficiency of red fruit (Pandanus conoideus Lam.) antioxidants in pregnant mice (Mus musculus) when administered before exposing them to lead, thereby revealing the potency of the plant against placental disorders during pregnancy. The objective of the present study was to evaluate the effect of red fruit oil antioxidants on the placenta of mice exposed to lead.

\section{METHODS}

\section{Research design}

The present study was an experimental study of completely randomized design conducted from October to December 2015 at the experimental animal and the veterinary pathology laboratories, Veterinary Faculty, Airlangga University.

\section{Experimental animals}

The subjects of this study were 20 pregnant Balb/c mice (Mus musculus) selected from among 35 three-month-old females weighing around 25-30 grams, who had been acclimatized for one week. The sample size was determined using Federer's formula, resulting in 4 pregnant mice per group. The optimal total sample size was 20 . The mice were assigned by simple random sampling to five groups. The negative control group (K) consisted of pregnant mice that were not exposed to lead on days 6 to 15 of gestation. The intervention group 0 ( $\mathrm{P} 0)$ consisted of pregnant mice exposed to lead acetate at an oral dose of $0.011 \mathrm{mg} / 20 \mathrm{~g} \mathrm{BW} /$ 
day, dissolved in $0.1 \mathrm{~mL}$ distilled water, on days 6 to 15 of gestation. The intervention groups (P1, $\mathrm{P} 2$, and $\mathrm{P} 3$ ) consisted of pregnant mice receiving red fruit oil at a dose of $0.3 \mathrm{~mL} / 20 \mathrm{~g} \mathrm{BW}, 0.8$ $\mathrm{mL} / 20 \mathrm{~g} \mathrm{BW}, 0.9 \mathrm{~mL} / 20 \mathrm{~g} \mathrm{BW}$, and being exposed to lead acetate one hour afterwards.

\section{Extraction of red fruit oil}

Selected ripe fruits were split lengthwise to remove the pith, then the fruit pulp was cut up into slices and rinsed. The pulp was steamed for 1-1.50 hours until well-done or soft, after which it was taken out to cool. A small quantity of water was added to the cooked slices, which were subsequently mashed into a paste. The fruit paste was screened to remove seed residues, then boiled for 4-5 hours. It was allowed to remain on the fire for 10 minutes until a black oil appeared on the surface. The boiled paste was removed from the fire and left standing for 24 hours, then the oil was carefully ladled to a transparent vessel, and left standing for 2 hours to separate the oil from the water and fruit paste. This last step was repeated several times until no more water remained under the layer of red fruit oil, which was then cooled and packaged.

\section{Estrus synchronization procedure}

Induction of estrus was effected by the use of pregnant mare serum gonadotropin (PMSG), followed by human chorionic gonadotropin (HCG) for estrus synchronization. The PMSG hormonal preparation was administered intraperitoneally at a dose of $5 \mathrm{IU}$, while $5 \mathrm{IU}$ of HCG was given 48 hours afterwards. ${ }^{(9)}$

\section{Intervention}

The hormonally-induced females were subsequently mated with the stud male by monomating. Mated females were identified by the formation of a vaginal plug 17 hours after mating. The presence of a vaginal plug is considered indicative of copulation and day 0 of gestation. The dose of $4 \mathrm{mg} / \mathrm{kg} \mathrm{BW}$ of lead for rats was converted to a dose of $0.011 \mathrm{mg} / 20 \mathrm{~g}$ $\mathrm{BW}$ for mice.
The intervention groups $\mathrm{P} 1, \mathrm{P} 2$, and $\mathrm{P} 3$ received red fruit antioxidants one hour before lead exposure. The lead exposure dose of 0.011 $\mathrm{mg} / 20 \mathrm{~g} \mathrm{BW}$ for the mice was based on the study of Aprioku and Siminialayi ${ }^{(10)}$ who proved in Wistar rats that at a dose of $4 \mathrm{mg} / \mathrm{kg} \mathrm{BW}$, lead exposure was capable of decreasing the number of births and of causing teratogenic effects in the form of abnormally-formed skulls, short forelimbs, and absence of hindlimbs in the fetus. The three doses of red fruit antioxidants were obtained from the study of Udju et al. ${ }^{(11)}$ who demonstrated that red fruit antioxidants at a dose of $1199.25 \mathrm{mg} / \mathrm{kg}$ BW could reduce total cholesterol concentrations in male Swiss albino mice. There are no previous data regarding the effect of red fruit administration on caspase expression in lead exposed mice.

The interval between red fruit antioxidant administration and lead exposure is known from study results showing that the concomitant administration of vitamin $\mathrm{C}$ and vitamin $\mathrm{E}$ with lead may protect cells from damage by free radicals during reproduction and fertilization. ${ }^{(7)}$ The one-hour interval between administration of antioxidants and lead is presumably effective in protecting the body against free radicals.

\section{Measurements}

The trophoblast cell count was performed in five fields of view. Trophoblast cells are located in the floating villi of the placenta, so that the five fields of view comprise 5 floating villi. Floating villi are characterized by the presence of trophoblast cells, Hofbauer cells, and blood vessels. The scoring of caspase- 9 expressing placental trophoblast cells was by means of a modified semiquantitative IRS scale of Remmele, in which the scores are obtained by multiplying the percentage of positive cells and the intensity of the color reaction. ${ }^{(12)}$

\section{Statistical analysis}

Caspase- 9 expression scores were analyzed by means of the Kruskal-Wallis test, followed by the Mann Whitney test. Trophoblast cell counts 
Table 1. Mean distribution of normal trophoblasts and caspase-9 expression, by intervention groups in pregnant mice (Mus musculus)

\begin{tabular}{lcccccc}
\hline & K- & P0 & P1 & P2 & P3 & P \\
\hline Normal trophoblasts & $31.10 \pm$ & $13.55 \pm$ & $21.85 \pm$ & $25.10 \pm$ & $25.50 \pm$ & 0.028 \\
& 9.67 & 1.11 & 10.37 & 3.49 & 3.46 & \\
Caspase-9 expression & 6.25 & 18.50 & 13.63 & 8.50 & 5.63 & 0.008 \\
\hline
\end{tabular}

$\mathrm{K}-$ = pregnant mice not exposed to lead on days 6-15 of gestation; $\mathrm{P} 0=$ pregnant mice exposed to lead at $0.011 \mathrm{mg} / 20 \mathrm{~g}$ $\mathrm{BW} /$ day dissolved in $0.1 \mathrm{~mL}$ of distilled water on days 6-15 of gestation; P1, P2, and P3 = pregnant mice given red fruit at $0.3 \mathrm{~mL} / 20 \mathrm{~g} \mathrm{BW}, 0.8 \mathrm{~mL} / 20 \mathrm{~g} \mathrm{BW}$, and $0.9 \mathrm{~mL} / 20 \mathrm{~g} \mathrm{BW}$ and then exposed to lead; Significant at $\mathrm{p}<0.05$

were analyzed by one-way ANOVA, followed by Duncan's test, at a significance level of 0.05

\section{Ethical clearance}

Ethical clearance for the present study was obtained from the Research Ethics Commission, Veterinary Faculty, Airlangga University, Surabaya.

\section{RESULTS}

From the results shown in Tables 1 and 2 it is apparent that administration of red fruit antioxidants to pregnant mice of intervention groups 2 and 3, before they were exposed to lead, was capable of substantially decreasing caspase9 expression in placental trophoblast cells.

In general the normal trophoblast cell counts differed considerably. According to one-way ANOVA, there were significant differences in mean trophoblast cell counts between groups $(\mathrm{p}<0.05)$ (Table 1). This was followed by Duncan's test to find differences between intervention groups.

The results of Duncan's test for mean normal trophoblast cell count and SD showed that in the negative control group, i.e. the group of pregnant mice without lead exposure or red fruit administration, there were significant differences with the intervention group zero, i.e. the group of pregnant mice receiving only lead exposure. In contrast, there were no significant differences between the negative control group and intervention groups 1,2 , and 3 , i.e. the groups of pregnant mice receiving red fruit antioxidants at different doses, and one hour afterwards being exposed to lead. However, there were significant differences between the intervention group 0 and the three intervention groups 1, 2, and 3 (Table 2). In the intervention group given red fruit at 0.9 $\mathrm{mL} / 20 \mathrm{~g} \mathrm{BW}$ and lead exposure one hour afterwards (P3) there was a significant increase of $88.2 \%$ in trophoblast cell count, in comparison with the group exposed to lead at $0.011 \mathrm{mg} / 20 \mathrm{~g}$ $\mathrm{BW} /$ day (P0) $(\mathrm{p}=0.024)$. There was also a significant reduction of $70.8 \%$ in caspase-9 expression of group P3 ( $\mathrm{p}=0.020)$ (Table 2).

Table 2 . Results of multiple comparisons test

\begin{tabular}{ccc}
\hline & $\begin{array}{c}\text { Mean } \\
\text { difference }\end{array}$ & p \\
\hline Norm al trophoblasts & 1755 & 0.002 \\
K-P0 & 9.25 & 0.071 \\
P1 & 6.00 & 0.227 \\
F2 & 5.60 & 0.258 \\
P3 & 5.30 & 0.102 \\
P0 P1 & 1055 & 0.028 \\
F2 & 1195 & 0.024 \\
P3 & 3.25 & 0.505 \\
P1 P2 & 4.65 & 0.455 \\
F3 & 0.40 & 0.934 \\
P2 P3 & & \\
Caspase-9 expre sion & 4.35 & 0.021 \\
K-P0 & 2.85 & 0.021 \\
P1 & 1.80 & 0.559 \\
F2 & 1.25 & 0.765 \\
P3 & 1.50 & 0.021 \\
P0 P1 & 1055 & 0.021 \\
F2 & 13.10 & 0.020 \\
P3 & 1.05 & 0.191 \\
P1 P2 & 1.60 & 0.020 \\
F3 & 0.55 & 0.465 \\
P2 P3 & &
\end{tabular}

$\mathrm{K}-=$ pregnant mice not exposed to lead on days 6-15 of gestation; $\mathrm{P} 0=$ pregnant mice exposed to lead at $0.011 \mathrm{mg} /$ $20 \mathrm{~g} \mathrm{BW} /$ day dissolved in $0.1 \mathrm{~mL}$ of distilled water on days 6-15 of gestation; $\mathrm{P} 1, \mathrm{P} 2$, and $\mathrm{P} 3=$ pregnant mice given red fruit at $0.3 \mathrm{~mL} / 20 \mathrm{~g} \mathrm{BW}, 0.8 \mathrm{~mL} / 20 \mathrm{~g} \mathrm{BW}$, and $0.9 \mathrm{~mL} / 20 \mathrm{~g}$ $\mathrm{BW}$ and then exposed to lead 
In immunohisto chemical and HE stained placental slide preparations, the intervention group 0 receiving lead exposure only showed a reduction in normal trophoblast cell count in comparison with the negative control group (Figure 1 and 2). With regard to red fruit doses, intervention group 1 given red fruit antioxidants at $0.3 \mathrm{~mL} / 20 \mathrm{~g} \mathrm{BW}$, yielded no significant differences with intervention group 0 , since the normal trophoblast cell counts approximated those of intervention group 0 . In contrast, intervention groups 2 and 3 yielded significant differences with intervention group 0 , since the normal trophoblast cell counts approximated those of the negative control group.

\section{DISCUSSION}

This study showed that there was increased caspase-9 expression in intervention group 0 (lead exposure only). The three intervention groups showed low caspase-9 expression, when compared with intervention group 0 . This is because lead as a toxicant causes damage to both the plasma membranes and the membranes of internal organelles, and also causes lipid peroxidation.

The membranes of mitochondria and microsomes are very sensitive to lipid peroxidation, because of the high polyunsaturated fatty acid (PUFA) content of the
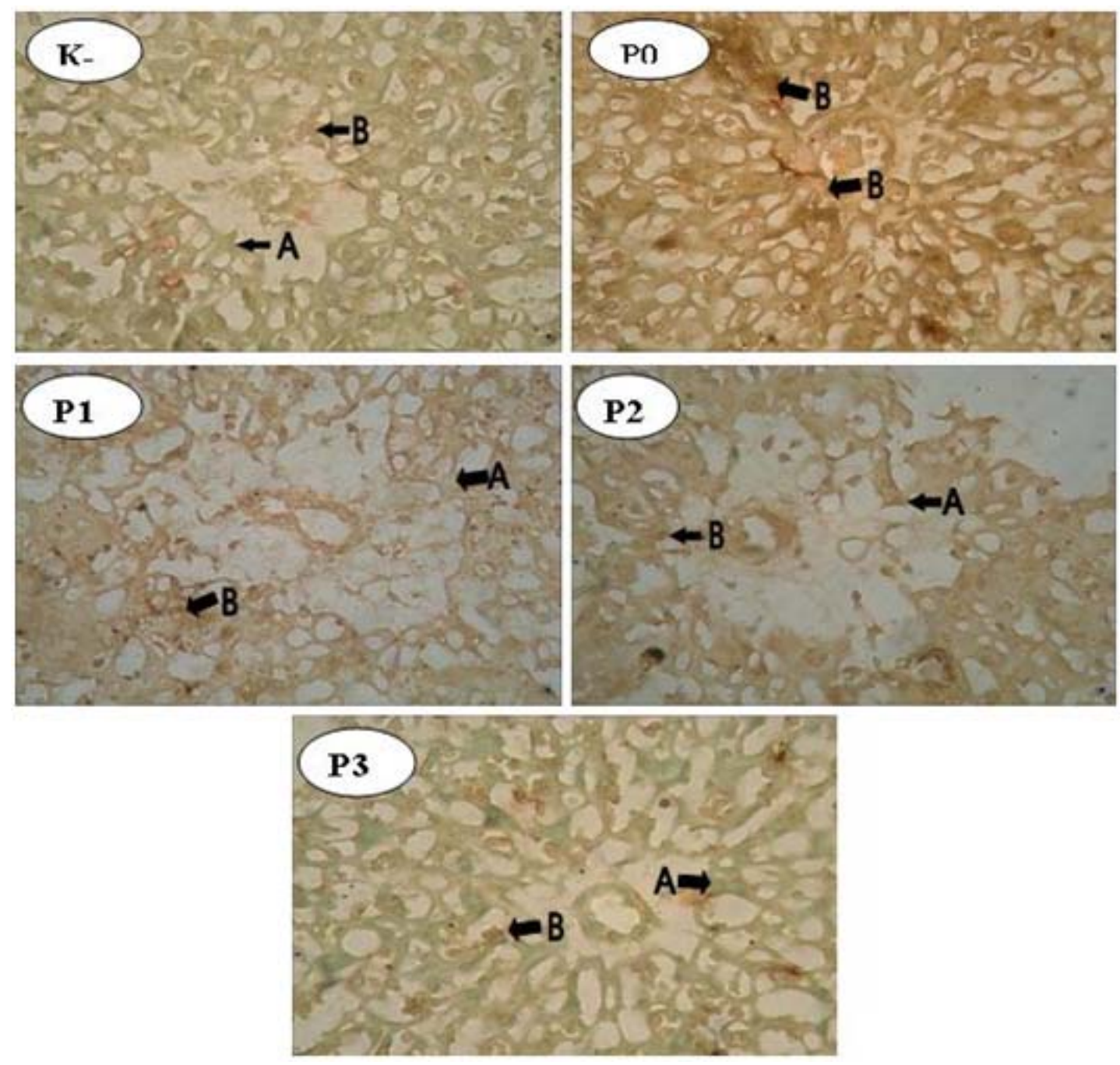

Figure 1. Caspase-9 expression in placenta of pregnant mice (Mus musculus) for each intervention. (A) not showing caspase-9 expression and (B) showing caspase-9 expression. (immunohistochemical staining; 400x). 

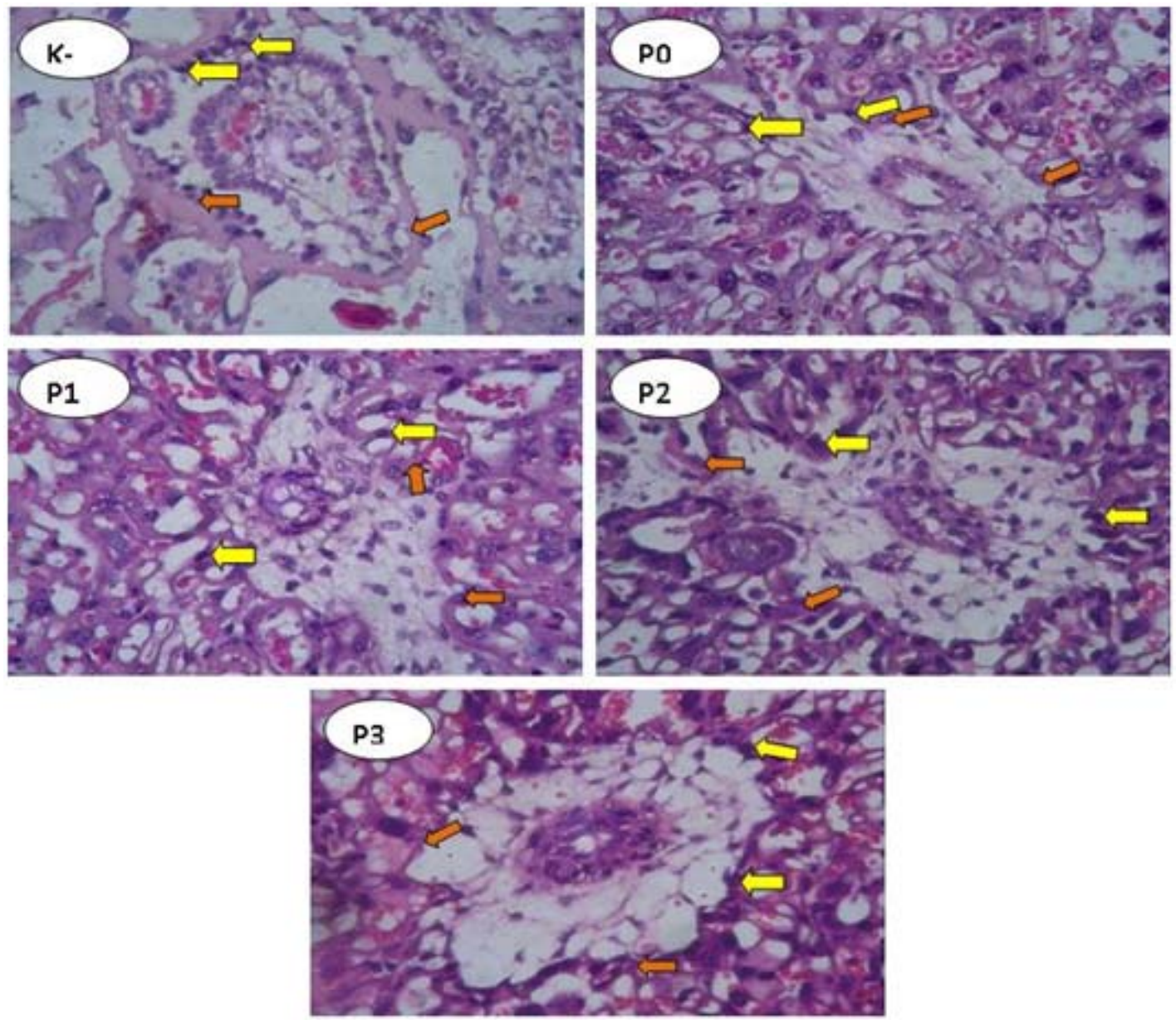

Figure 2. Histopathology of normal trophoblasts in pregnant mice (Mus musculus) before lead exposure. Yellow arrows $=$ normal trophoblasts; red arrows $=$ necrosis of trophoblasts $($ Hematoxylin Eosin stain, 400x $)$

phospholipid membranes. ${ }^{(13)}$ Lead exposure during organogenesis causes stress in the placental cells and in the mitochondria of these cells, resulting in the expression of several proteins by these cells, such as Bax, a protein carrier of apoptosis signals from within the cells. Excessive Bax expression in the cytoplasm may damage the mitochondrial membrane so that the cell loses energy. The damaged mitochondrial membrane releases one of the most important proteins, i.e. cytochrome-c, into the cytoplasm. The expression of Bcl-2 protein increases, represses Bax and inhibits apoptosis. This causes release of mitochondrial cytochrome-c into the cytosol, where it promotes oligomerization of apoptotic protease activating factor-1 (Apaf-1), procaspase- 9 and ATP, forming a complex called the apoptosome. The apoptosome is recruited and activates caspase- 9 , which in turn promotes caspase- 3 activation. This mechanism constututes the intrinsic pathway of apoptosis.

The high level of apoptosis in this study is reflected in the brownish colored caspase- 9 antibody-antigen complexes. This proves that caspase-9 plays a role in the apoptosis of placental cells at the final stages of pregnancy. The study results show that caspase- 9 is expressed by placental cells, i.e. trophoblast cells, decidual cells, fibroblasts, and placental blood cells. Caspase-9 induces cell death through the intrinsic pathway, which is activated through the stress induced pathway (mitochondria-mediated pathway). ${ }^{(14)}$

Caspase- 9 expression was also seen in the negative control group, because apoptosis of placental cells is a physiological process at the approach of parturition. Therefore the negative control group still exhibited a brown color, but 
not more than did group P0 receiving lead exposure. Apoptosis of decidual cells and trophoblast cells increases with age of gestation in normal pregnancies. ${ }^{(15)}$ However, Qumsiyeh et al. ${ }^{(16)}$ state that apoptosis of decidual cells and chorionic villi in cases of spontaneous abortion is more than in normal pregnancies. Physiologically, apoptosis in trophoblast cells occurs in the third trimester. With increasing age of gestation, the rate of apoptosis is normally increased, so that the number of living cells decreases.

Placental trophoblast cells differentiate into cytotrophoblasts, then the cytotrophoblasts fuse with one another, forming the syncytiotrophoblast. In addition, the cytotrophoblasts also differentiate into spongiotrophoblasts. In humans and mice, the trophoblasts at the end of gestation differentiate into glycogen cells that play a role in energy storage. Furthermore, at the end of gestation the trophoblasts normally also undergo apoptosis at the approach of parturition. Lead exposure influences the morphology and physiological reponse of the rat placenta, particularly in the placental labyrinth, i.e. the confluence of the maternal and fetal circulation. The presence of lead causes high ROS levels in placental cells, including vascular endothelial cells, resulting in necrosis and apoptosis of these endothelial cells. Damage to the blood vessels triggers a physiological response to form new blood vessels (angiogenesis). ${ }^{(17)}$ Lead results in a high rate of cell death and affects the physiological response and morphology of the rat placenta. Lead exposure during organogenesis in pregnant mice may cause accelerated apoptosis, thus resulting in abortion. Increased placental cell death and high levels of inflammation induces secretion of inflammatory cytokines in the blood, while within the cells there is oxidative stress. Remodelling of placental vascularization does not occur because the majority of placental cells have undergone normal apoptosis, with extremely high cell death rates and decreased supply of nutrients and vascularization, resulting in abortion.

One method to find abnormalities of pregnancy due to lead is to determine the level of apoptosis of placental cells, and one of its indicators is expression of caspase-9 protein in placental trophoblasts. The presence of caspase9 demonstrates the occurrence of apoptosis in the placenta, and may be determined by immunohistochemical techniques.

In group P3 receiving the highest dose of antioxidants there was a substantial difference with group P0, but none with group P2. This was because the dose range between groups $\mathrm{P} 2$ and $\mathrm{P} 3$ was not too great. However, if compared with group P1 it may be seen that the doses of groups $\mathrm{P} 2$ and $\mathrm{P} 3$ were more influential in decreasing caspase-9 expression, showing that at these doses the antioxidants were capable of reducing caspase9 expression. The antioxidants contained in red fruit function as immunosuppressor, thus acting to decrease caspase- 9 expression in trophoblasts as a result of induction by lead. Therefore red fruit antioxidants decrease apoptosis of the cells and increase the number of normal trophoblasts.

Group P0 showed a substantial difference from the other intervention groups, whether the negative control group or the intervention groups. The lead exposure presumably induced many of the placental trophoblasts to undergo necrosis due to the presence of the inflammatory cytokine TNF$\alpha$, that is capable of causing apoptosis of trophoblasts.

In contrast, among the intervention groups receiving red fruit antioxidants before lead exposure, it was found that groups $\mathrm{P} 2$ and $\mathrm{P} 3$ did not substantially differ from the negative control group, but did substantially differ from group P0. This was due to the betacarotene and tocopherol content of red fruit as a source of natural antioxidants capable of protecting the body against ROS. Antioxidants are not only important for preventing oxidative stress and tissue damage, but also for preventing increased production of proinflammatory cytokines, that are the result of continuous activation of the defense system. The benefit of red fruit antioxidants is to disrupt the free radical chain reaction, such as is done by vitamin $\mathrm{E}$ (alpha tocopherol), vitamin $\mathrm{C}$ (ascorbic acid), and vitamin A (betacarotene). 
Tocopherol and betacarotene are antioxidants that can terminate the free radical chain reaction. ${ }^{(18)}$ Tocopherol has the ability to terminate lipid peroxidation by donating one hydrogen atom from the $\mathrm{OH}$ group to the lipid peroxyl radical, so that it becomes less reactive and does not cause damage. When there are free radicals, lipid peroxides increase due to reactions between lipids and free radicals. The doses of 0.8 $\mathrm{mL} / 20 \mathrm{~g} \mathrm{BW}$ and $0.9 \mathrm{ml} / 20 \mathrm{~g} \mathrm{BW}$ of red fruit antioxidants in groups $\mathrm{P} 2$ and $\mathrm{P} 3$ showed an increase in normal trophoblast cell counts, which was greater than the increase produced by the dose of $0.3 \mathrm{~mL} / 20 \mathrm{~g} \mathrm{BW}$. Primary antioxidants are capable of cleaving free radicals by initiating a chain reaction through chain-breaking, i.e. by donating a free electron to ROS and lipid radicals that are produced in biological systems and converting them to more stable molecules. ${ }^{(19)}$ Tocopherol when given to lead-exposed rats can neutralize lead toxicity by cleaving free radicals and preventing oxidative stress. ${ }^{(20)}$ Tocopherol as an antioxidant acts by competitive inhibition of lead and prevents the formation of lipid peroxides as a result of lead exposure.

The carotenoids contained in red fruit antioxidants may induce metabolic enzymes so as to prevent cell damage or death caused by lead. ${ }^{(21)}$ All carotenoids, whether as provitamin A or not, may act as antioxidant. Carotenoids also prevent the formation of lipid peroxides and bind to free radicals. The antioxidant mechanism of carotenoids is through quenching of singlet oxygen and subsequently interacting with free radicals. ${ }^{(22)}$

The limitations of this study are firstly, that the sampling was done in stages, since not all of the mice were found to be pregnant. Secondly, that several oxidative stress parameters were not measured, e.g. malondialdehyde (MDA) and superoxide dismutase (SOD). In accordance with the results of this study, its clinical implication is that the use of antioxidants as a preventive measure, both in humans and animals, is urgently required, in view of the occurrence of heavy metal pollution that may affect reproductive health. Further studies are needed to evaluate red fruit administration at various time points before lead exposure.

\section{CONCLUSIONS}

Administration of red fruit to pregnant mice before lead exposure has the potential to increase the normal trophoblast cell count by $88.2 \%$ and decrease caspase- 9 expression by $70.8 \%$. Red fruit is a potential protective agent against ROSmediated disorders.

\section{CONFLICT OF INTERESTS}

None declared.

\section{ACKNOWLEDGEMENT}

We thank the staff of the Embryology and Veterinary Pathology laboratories. Veterinary Faculty, Airlangga University for support in the completion and publication of this study.

\section{REFERENCES}

1. Barness EG. Teratogenic causes of malformations. Ann Clin Lab Sci 2010;40:99114.

2. Garcia-Nìno WR, Chaverri JP. Protective effect of curcumin against heavy metals-induced liver damage. Food Chem Toxicol 2014;69:182-201.

3. Levy R, Smith SD, Yusuf K, et al. Trophoblast apoptosis from pregnancies complicated by fetal growth restriction is associated with enhanced p53 expression. Am J Obstet Gynecol 2002; 186: 1056-61.

4. Sarungallo ZL, Hariyadi P, Andarwulan N, et al. Analysis of $\alpha$-cryptoxanthin, $\beta$-cryptoxanthin, $\alpha$-carotene, and $\beta$-carotene of Pandanus conoideus oil by high-performance liquid chromatography (HPLC). Procedia Food Sci 2015;3:231-3.

5. Dearth RK, Hiney JK, Srivastava V, et al. Effects of lead $(\mathrm{Pb})$ exposure during gestation and lactation on female pubertal development in the rat. Reprod Toxicol 2002;16:343-53.

6. Isradji I. Pengaruh pemberian $\mathrm{Pb}$-asetat terhadap fertilitas mencit jantan, dimonitor melalui jumlah kebuntingan dan jumlah anak sekelahiran. Sains Medika 2010;2:2:170-177. 
7. Sharma RN, Qureshi SM, Panwar K. Lead induced infertility in Swiss mice and role of antioxidants. Universal J Environ Res Technol 2012;2:72-82.

8. Rohman A, Riyanto S, Yuniarti N, et al. Antioxidant activity, total phenolic, and total flavaonoid of extracts and fractions of red fruit (Pandanus conoideus Lam). Int Food Res J 2010; 17:97-106.

9. Widjiati AWR, Arifin MZ. Pengaruh berbagai konsentrasi krioprotektan propanediol pada proses vitrifikasi terhadap viabilitas embrio mencit pasca thawing. Veterinaria Medika 2011; $4: 2$.

10. Aprioku JS, Siminialayi IM. Maternal lead exposure and pregnancy outcome in Wistar albino rats. J Toxicol Environ Health Sci 2013; 5:185-93.

11. Udju IST, Martono Y, Soetjipto H. Ekstrak enzimatis antioksidan buah merah (Pandanus conoideus Lam.) sebagai antikolesterol terhadap mencit putih jantan galur swiss. Prosiding Seminar Nasional Sains dan Pendidikan Sains VII UKSW. Salatiga;2012.p.117-26.

12. Nowak M, Madej JA, Dziegeil P. Intensity of Cox2 expression in cells of soft tissue fibrosarcomas in dogs as related to grade of tumour malignancy. Bull Vet Inst Pulawy 2007; 51:275-9.

13. Suryohudoyo P. Kapita selekta ilmu kedokteran molekuler. Jakarta: Sagung Seto;2007.

14. McIlwain DR, Berger T, Mak TW. Caspase functions in cell death and disease. Cold Spring Harb Perspect Biol 2013;5:a008656.

15. Halperin R, Peller S, Sandbank J, et al. Expression of the p53 gene and apoptosis in gestational tropoblastic disease. Placenta 2000; 21:58-62.
16. Qumsiyeh MB, Kim KR, Ahmed MN, et al Cytogenetics and mechanisms of spontaneous abortions: increased apoptosis and decreased cell proliferation in chromosomally abnormal villi. Cytogenet Cell Genet 2000;88:230-5.

17. Veras MM, Damaceno-Rodrigues NR, Caldini EG, et al. Particulate urban air pollution affects the functional morphology of mouse placenta. Biol Reprod 2008;79:578-84.

18. Christijanti W, Utami NR, Iswara A. Pemberian antioksidan vitamin $\mathrm{C}$ dan $\mathrm{E}$ terhadap kualitas spermatozoa tikus putih terpapar allethrin. Biosaintifika 2010;2:18-26.

19. Vaya J, Aviram M. Nutritional antioxidants: mechanisms of action, analyses of activities and medical applications. Curr Med Chem Imm Endo Metab Agents 2001;1.

20. Sajitha GR, Jose R, Andrews A, et al. Garlic oil and vitamin E prevent the adverse effects of lead acetate and ethanol separately as well as in combination in the drinking water of rats. Indian Clin Biochem 2010;25:280-8.

21. Sharma B, Singh S, Siddiqi NJ. Biomedical implications of heavy metals induced imbalances in redox systems. Bio Med Res Int 2014, Article ID 640754, 26 pages http://dx.doi.org/10.1155/ 2014/640754.

22. Polyakov NE, Foscan AL, Bowman MK, et al. Free radical formation in novel carotenoid metal ion complexes with astaxanthin. J Phys Chem B 2010;114:16968-77. 